Check for updates

Cite this: RSC Adv., 2017, 7, 18561

\title{
Conversion of cellulose into lactic acid using zirconium oxide catalysts $\uparrow$
}

\author{
Panya Wattanapaphawong, ${ }^{\text {ab }}$ Prasert Reubroycharoen ${ }^{\text {bc }}$ \\ and Aritomo Yamaguchi (iD) *ad
}

The possibility of converting cellulose into lactic acid using stable, easily prepared solid catalysts has attracted much attention. In this study, the catalytic activities of various transition metal oxides for cellulose conversion were determined; $\mathrm{ZrO}_{2}$ showed the highest activity for lactic acid production from cellulose. Various types of $\mathrm{ZrO}_{2}$ were tested for catalytic activity. The correlation between lactic acid yields and the characteristic properties of the $\mathrm{ZrO}_{2}$ indicated that the concentrations of acid and base sites on the $\mathrm{ZrO}_{2}$ played an important role in lactic acid production. The conversion of fructose into glyceraldehyde and dihydroxyacetone by a retro-aldol reaction was probably enhanced by the combination of acid and base sites on the $\mathrm{ZrO}_{2}$. The $\mathrm{ZrO}_{2}$ catalyst was stable in high-temperature water $(473 \mathrm{~K})$, and almost no $\mathrm{Zr}$ leached out of the catalyst into solution during the reaction.

Received 22nd December 2016 Accepted 22nd March 2017

DOI: 10.1039/c6ra28568f

rsc.li/rsc-advances the production rate is low, and (iii) edible carbohydrates are conventionally used as a starting material. ${ }^{9}$

The catalytic production of lactic acid from inedible cellulose has been discussed as an alternative to the fermentation process. High yields of lactic acid from cellulose have been achieved with homogeneous catalysts (68\% with $\mathrm{PbCl}_{2}$ (ref. 10) and $91 \%$ with $\mathrm{ErCl}_{3}$ (ref. 11)). However, use of homogeneous catalysts is compromised by difficulties associated with product separation from the catalysts and the recyclability of the catalysts. Heterogeneous catalysts are much better suited for cellulose conversion into lactic acid because they can be easily separated from the product; however, only a few such catalysts have been reported. Yang et al. obtained a $24 \%$ yield of lactic acid from cellulose using $\mathrm{LaCoO}_{3}$ perovskite metal oxide. ${ }^{12}$ Chambon et al. used AlW as a solid catalyst and obtained a $28 \%$ yield of lactic acid from cellulose, ${ }^{13}$ and Coman et al. have reported a $27 \%$ yield of lactic acid from cellulose using $\mathrm{NbF}_{5}-\mathrm{AlF}_{3}$ as a catalyst. ${ }^{14}$ One of the problems with these solid catalysts is that the metal species leach into solution; $2.4 \%$ and $1.5 \%$ of the Co and La, respectively, from $\mathrm{LaCoO}_{3}$ (ref. 12) and 1.5\% of the W from $\mathrm{AlW}^{\mathbf{1 3}}$ leached into solution. Also, the cost of preparation of these heterogeneous catalysts makes their industrial use problematic. A few simple metal oxides such as $\mathrm{ZrO}_{2}$ and $\mathrm{TiO}_{2}$ have been found to be stable solid catalysts in high-temperature water. ${ }^{15,16}$ In this study, we aim to find a new heterogeneous catalyst, which is lower in cost than the reported heterogeneous catalysts, without leaching of metal species. We report cellulose conversion into lactic acid using simple metal oxides as stable, easily prepared solid catalysts. We found that $\mathrm{ZrO}_{2}$ actively catalyzed the production of lactic acid (yield 21.2\%) from cellulose and that it was very stable in high-temperature water (473 K).

\footnotetext{
${ }^{a}$ National Institute of Advanced Industrial Science and Technology (AIST), 4-2-1 Nigatake, Miyagino, Sendai 983-8551, Japan. E-mail: a.yamaguchi@aist.go.jp ${ }^{b}$ Department of Chemical Technology, Faculty of Science, Chulalongkorn University, Pathumwan, Bangkok 10330, Thailand

${ }^{c}$ Center of Excellence on Petrochemical and Materials Technology, Chulalongkorn University Research Building, Bangkok 10330, Thailand

${ }^{d}$ JST, PRESTO, 4-2-1 Nigatake, Miyagino, Sendai 983-8551, Japan

$\dagger$ Electronic supplementary information (ESI) available. See DOI: 10.1039/c6ra28568f
} 


\section{Experimental}

\section{Catalysts}

Zirconium oxides $\left(\mathrm{ZrO}_{2}\right)$ were purchased from Hosokawa Micron Co. ( $\left.\mathrm{ZrO}_{2}-\mathrm{Hos}\right)$, Sigma-Aldrich Co., LLC. (Aldrich) $\left(\mathrm{ZrO}_{2}{ }^{-}\right.$ Ald), Nacalai Tesque, Inc. (Nacalai) $\left(\mathrm{ZrO}_{2}-\mathrm{Nac}\right)$, and Wako Pure Chemical Industries, Ltd. (Wako) $\left(\mathrm{ZrO}_{2}\right.$-Wak); standard samples were obtained from Daiichi Kigenso Kagaku Kogyo Co., Ltd. via the Catalysis Society of Japan (ZRO-6, ZRO-7, ZRO-8, and ZRO9). Yttria-stabilized zirconium oxide (YSZ) was purchased from Tosoh Co.; aluminum oxide $\left(\mathrm{Al}_{2} \mathrm{O}_{3}\right)$, iron oxide $\left(\mathrm{Fe}_{3} \mathrm{O}_{4}\right)$, and lanthanum oxide $\left(\mathrm{La}_{2} \mathrm{O}_{3}\right)$ from Aldrich; titanium oxide with anatase phase $\left(\mathrm{A}-\mathrm{TiO}_{2}\right)$, rutile phase $\left(\mathrm{R}-\mathrm{TiO}_{2}\right)$, and cerium oxide
(Shimadzu, GC-2014) with a flame ionization detector and an InertCap capillary column (GL Sciences Inc.); we used 1-butanol as the internal standard. Quantitative analyses of sugars such as glucose were conducted by high-performance liquid chromatography (Shimadzu, HPLC) with a refractive index detector (Shimadzu, RID-10A) and a UV-Vis detector (Shimadzu, SPD20AV) equipped with a Rezex RPM-Monosaccharide $\mathrm{Pb}+2$ column (Phenomenex). The amount of total organic carbon (TOC) in the liquid fraction was determined using a total organic carbon analyzer (Shimadzu, TOC- $\mathrm{V}_{\mathrm{CSN}}$ ). The conversion and product yields were calculated based on the dry weight and moles of carbon, respectively, in the cellulose and product as follows:

$$
\text { Conversion }(\%)=\left(1-\frac{(\text { weight } \text { of } \text { solid residue })-(\text { weight of solid catalyst })}{(\text { initial weight of cellulose })}\right) \times 100
$$

$\left(\mathrm{CeO}_{2}\right)$ from Kanto Chemical Co., Inc. (Kanto); vanadium oxide $\left(\mathrm{V}_{2} \mathrm{O}_{5}\right)$ from Rare Metallic Co., Ltd.; cerium oxide $\left(\mathrm{CeO}_{2}\right)$ (Kanto), thulium oxide $\left(\mathrm{Tm}_{2} \mathrm{O}_{3}\right)$ and yttrium oxide $\left(\mathrm{Y}_{2} \mathrm{O}_{3}\right)$ from Nippon Yttrium Co., Ltd. (NYC); hafnium oxide $\left(\mathrm{HfO}_{2}\right)$ and gallium oxide $\left(\mathrm{Ga}_{2} \mathrm{O}_{3}\right)$ from Wako; niobium oxide $\left(\mathrm{Nb}_{2} \mathrm{O}_{5}\right)$ from Koso Chemical; tantalum oxide $\left(\mathrm{Ta}_{2} \mathrm{O}_{5}\right)$ from Nacalai; and magnesium oxide (MgO) from Ube Industries, Ltd. These metal oxide catalysts were used without purification or pretreatment.

$\mathrm{ZrO}_{2}$ was also prepared by a precipitation method as follows. ${ }^{17}$ We dissolved $13.07 \mathrm{~g}$ of zirconyl chloride $\left(\mathrm{ZrOCl}_{2}\right.$ $\cdot 8 \mathrm{H}_{2} \mathrm{O}$ ) in $500 \mathrm{~cm}^{3}$ of water. The aqueous solution of $\mathrm{ZrOCl}_{2}$ $\cdot 8 \mathrm{H}_{2} \mathrm{O}$ was gradually dropped into $300 \mathrm{~cm}^{3}$ of a $0.1 \mathrm{~mol} \mathrm{dm}^{-3}$ of aqueous ammonia with stirring. More $0.1 \mathrm{~mol} \mathrm{dm}^{-3}$ ammonia solution was added until the $\mathrm{pH}$ of the obtained suspension reached 10 . This suspension was stirred for $1 \mathrm{~h}$ and then aged for $24 \mathrm{~h}$. The precipitate was separated from the aqueous solution by filtration, washed several times with distilled water, and then dried at $393 \mathrm{~K}$ overnight. The samples were calcined at temperatures of $773,873,973$, and $1073 \mathrm{~K}$ in air for $4 \mathrm{~h}$. These calcined samples are denoted as $\mathrm{ZrO}_{2}-X(X=$ calcination temperature).

\section{Reaction procedure}

The conversion of cellulose was carried out in a stainless steel batch reactor (OM Lab-Tech, MMJ-100) with an inner volume of $100 \mathrm{~cm}^{3}$. In a typical experiment, ball-milled cellulose (Merck Ltd., microcrystalline cellulose) ( $0.5 \mathrm{~g})$, metal oxide catalyst (1.0 $\mathrm{g}$ ), and water $(50 \mathrm{~g})$ were loaded into the reactor, and the reactor was purged with nitrogen gas $(0.1 \mathrm{MPa})$. The reactor was heated to $473 \mathrm{~K}$ and maintained at that temperature for $6 \mathrm{~h}$ with screw stirring. After the reaction, a mixture of liquid and solid was recovered and filtered to separate the solid materials from the liquid fraction. The solid residue was dried overnight at $333 \mathrm{~K}$, and the weight of the dry solid residue was recorded. Quantitative analyses of water-soluble chemicals such as lactic acid, levulinic acid, 5-hydroxymethylfurfural (HMF), and furfural in the liquid fraction were performed by gas chromatography

$$
\begin{aligned}
\text { Product yield }(\%)= & \left(\frac{\text { moles of carbon atoms in product }}{\text { moles of carbon atoms in cellulose }}\right) \\
& \times 100
\end{aligned}
$$

\section{Characterization}

$\mathrm{X}$-ray diffraction (XRD) patterns of the catalysts were recorded using a Rigaku SmartLab with $\mathrm{Cu} K \alpha$ radiation $(\lambda=0.15406 \mathrm{~nm})$ under $30 \mathrm{~mA}$ current and $40 \mathrm{kV}$ voltages in the $2 \theta$ range of $5-90^{\circ}$ with a $2 \theta$ step size of $0.02^{\circ}$.

Nitrogen adsorption and desorption measurements at $77 \mathrm{~K}$ were carried out on a Micromeritics 3FLEX 3500 chemisorption analyzer for samples degassed at $573 \mathrm{~K}$ for $4 \mathrm{~h}$. The specific surface areas of the catalysts were determined by the BrunauerEmmett-Teller (BET) method.

Temperature-programmed desorption of ammonia $\left(\mathrm{NH}_{3}-\right.$ TPD) was carried out with a TPD-1-AT instrument (Bel Japan, Inc.). The sample ( $c a .0 .05 \mathrm{~g}$ ) was loaded in a quartz tube and pretreated at $773 \mathrm{~K}$ in flowing helium for $1 \mathrm{~h}$. After cooling in flowing helium to $373 \mathrm{~K}$, the sample was saturated in $5 \%$ ammonia diluted with helium $\left(0.5 \mathrm{~cm}^{3} \mathrm{~s}^{-1}\right)$ for $30 \mathrm{~min}$, after which the flowing gas was switched to helium at a flow rate of $0.83 \mathrm{~cm}^{3} \mathrm{~s}^{-1}$ for $1 \mathrm{~h}$. Finally, the sample was heated at a constant rate of $10 \mathrm{~K} \mathrm{~min}^{-1}$ to $953 \mathrm{~K}$. The ammonia signal was analyzed with an online quadrupole mass spectrometer.

Temperature-programmed desorption of carbon dioxide $\left(\mathrm{CO}_{2}\right.$-TPD) was carried out on a Micromeritics 3FLEX 3500 chemisorption analyzer with an online quadrupole mass spectrometer. The sample ( $c a .0 .2 \mathrm{~g}$ ) was loaded into a quartz tube and pretreated at $773 \mathrm{~K}$ in flowing helium for $1 \mathrm{~h}$. After cooling in flowing helium to $323 \mathrm{~K}$, the sample was saturated in ${\mathrm{a} \mathrm{CO}_{2}}$ flow $\left(0.5 \mathrm{~cm}^{3} \mathrm{~s}^{-1}\right)$ for $30 \mathrm{~min}$. The flowing gas was switched to helium $\left(0.83 \mathrm{~cm}^{3} \mathrm{~s}^{-1}\right)$ for $1 \mathrm{~h}$, and then the sample was heated at a constant rate of $10 \mathrm{~K} \mathrm{~min}^{-1}$ to $953 \mathrm{~K}$.

The concentration of zirconium species in liquid solution was determined using an inductively coupled plasma (ICP) 
atomic emission spectrometer (SPS4000, SII NanoTechnology Inc.).

\section{Results and discussion}

\section{Catalyst screening}

The results of the catalytic conversion of cellulose at $473 \mathrm{~K}$ using various transition metal oxides as solid catalysts and using hydrothermal conversion without solid catalysts as a reference are summarized in Table 1 . The fact that the cellulose conversion was $86.3 \%$ without catalysts showed that cellulose hydrolysis occurred in water at $473 \mathrm{~K}$. In this study, we used cellulose after the ball-milling treatment to decrease the crystallinity of cellulose and increase the cellulose hydrolysis. ${ }^{18,19}$ Without solid catalysts, however, only a $0.7 \%$ yield of lactic acid could be obtained; the yields of glucose, HMF, and levulinic acid, however, were $6.6 \%, 16.4 \%$, and $4.0 \%$, respectively. It has been reported that glucose and its isomer fructose are dehydrated into HMF in water with or without a Brønsted acid ${ }^{20}$ and that levulinic acid is obtained from $\mathrm{HMF}^{21}$ (Scheme 1). Previous studies have indicated that obtaining lactic acid requires conversion of fructose into glyceraldehyde and dihydroxyacetone by a retro-aldol reaction ${ }^{22,23}$ (Scheme 1) instead of fructose dehydration into HMF. The yield of lactic acid was increased by using the metal oxides $\mathrm{ZrO}_{2}, \mathrm{CeO}_{2}, \mathrm{HfO}_{2}, \mathrm{Al}_{2} \mathrm{O}_{3}$, and $\mathrm{V}_{2} \mathrm{O}_{5}$, the indication being that these catalysts enhanced the conversion of fructose into glyceraldehyde and dihydroxyacetone. The active sites associated with this step will be discussed later. $\mathrm{ZrO}_{2}$ was the most effective catalyst in converting cellulose into lactic acid, the yield of lactic acid being $21.2 \%$. As mentioned in the Introduction section, $\mathrm{ZrO}_{2}$ is known to be a stable solid catalyst in high-temperature water. ${ }^{15,16}$ We measured how much $\mathrm{Zr}$ leached into liquid solution by ICP. Only $10^{-4} \%$ (almost zero) of the $\mathrm{Zr}$ leached out from $\mathrm{ZrO}_{2}$ into the water during the reaction, much smaller than the $1.5 \%$ of $\mathrm{W}$ that leaches from AlW. ${ }^{13} \mathrm{We}$ therefore selected $\mathrm{ZrO}_{2}$ as the catalyst for cellulose conversion into lactic acid.

\section{Reaction conditions}

The reaction conditions such as reaction time and reaction temperature were optimized to obtain a high yield of lactic acid from cellulose. The conversion of cellulose using $\mathrm{ZrO}_{2}$ (ZRO-7) at $473 \mathrm{~K}$ was carried out for reaction times of $3-7.5 \mathrm{~h}$ (Fig. 1). The yield of lactic acid increased from $14.3 \%$ to $21.2 \%$ with increasing reaction time from 3 to $6 \mathrm{~h}$. When the reaction time was increased to $7.5 \mathrm{~h}$, the yield of lactic acid decreased, presumably because the prolonged reaction time led to decomposition of lactic acid. We checked the stability of lactic acid with $\mathrm{ZrO}_{2}$ under the same conditions as the reaction (473 $\mathrm{K}, 6 \mathrm{~h}$ ). The recovery of lactic acid was $90.8 \%$, the indication being that some of lactic acid decomposed or polymerized into other materials. This result can explain the decrease of lactic acid yield between 6 and $7.5 \mathrm{~h}$.

The conversion of cellulose using $\mathrm{ZrO}_{2}$ (ZRO-7) was carried out at temperatures in the range $453-483 \mathrm{~K}$ (Fig. 2). The cellulose conversion increased with increasing reaction temperature, and the yield of lactic acid also increased with increasing reaction temperature up to $473 \mathrm{~K}$. The lactic acid yield, however, decreased between 473 and $483 \mathrm{~K}$, probably because of the decomposition of lactic acid at the higher reaction temperature. We also checked the results at 453 and $463 \mathrm{~K}$ for reaction times up to $24 \mathrm{~h}$ (Fig. S1 and S2 $†$ ). At 453 and $463 \mathrm{~K}$, the yield of lactic acid increased with increasing reaction time from 3 to $18 \mathrm{~h}$ (maximum yield $16.8 \%$ at $463 \mathrm{~K}$ ); however, lactic acid yield decreased slightly between 18 and $24 \mathrm{~h}$ (Fig. S1 and S2†). We also checked the results at $483 \mathrm{~K}$ for reaction times of no more than $7.5 \mathrm{~h}$ (Fig. S3†). The maximum yield (17.6\%) at $483 \mathrm{~K}$ was

Table 1 Conversion of cellulose into various chemicals using various metal oxide catalysts ${ }^{a}$

\section{Yield (\%)}

\begin{tabular}{|c|c|c|c|c|c|c|c|}
\hline Catalyst & $\begin{array}{l}\text { Conversion } \\
(\%)\end{array}$ & Lactic acid & Glucose & $\mathrm{HMF}$ & $\begin{array}{l}\text { Levulinic } \\
\text { acid }\end{array}$ & Furfural & Others $^{b}$ \\
\hline No catalyst & 86.3 & 0.7 & 6.6 & 16.4 & 4.0 & 5.6 & 33.0 \\
\hline $\mathrm{ZrO}_{2}(\mathrm{ZRO}-7)$ & 87.3 & 21.2 & 0.0 & 0.5 & 3.2 & 0.6 & 39.7 \\
\hline $\mathrm{Al}_{2} \mathrm{O}_{3}$ & 87.7 & 8.7 & 0.0 & 0.9 & 12.1 & 0.3 & 32.9 \\
\hline $\mathrm{A}-\mathrm{TiO}_{2}$ & 100.0 & 2.8 & 0.0 & 3.8 & 7.5 & 2.0 & 43.1 \\
\hline $\mathrm{R}-\mathrm{TiO}_{2}$ & 88.2 & 1.6 & 0.0 & 13.3 & 5.6 & 2.0 & 45.0 \\
\hline $\mathrm{Fe}_{3} \mathrm{O}_{4}$ & 75.7 & 2.9 & 1.7 & 17.6 & 0.3 & 1.6 & 33.6 \\
\hline $\mathrm{V}_{2} \mathrm{O}_{5}$ & 95.6 & 6.1 & 0.0 & 0.1 & 4.1 & 2.0 & 46.5 \\
\hline $\mathrm{CeO}_{2}$ & 97.4 & 12.9 & 0.1 & 1.6 & 0.7 & 0.5 & 46.6 \\
\hline $\mathrm{Tm}_{2} \mathrm{O}_{3}$ & 94.2 & 2.6 & 0.0 & 0.7 & 0.4 & 0.3 & 50.5 \\
\hline $\mathrm{HfO}_{2}$ & 100.0 & 12.5 & 0.0 & 5.2 & 2.4 & 1.3 & 44.6 \\
\hline $\mathrm{Ga}_{2} \mathrm{O}_{3}$ & 88.3 & 2.5 & 5.7 & 1.7 & 3.4 & 2.3 & 54.1 \\
\hline $\mathrm{Nb}_{2} \mathrm{O}_{5}$ & 87.9 & 0.6 & 5.4 & 12.3 & 1.9 & 2.2 & 46.2 \\
\hline $\mathrm{Ta}_{2} \mathrm{O}_{5}$ & 98.2 & 0.6 & 5.3 & 14.7 & 1.4 & 3.5 & 44.7 \\
\hline $\mathrm{La}_{2} \mathrm{O}_{3}$ & 53.2 & 1.1 & 0.0 & 0.0 & 0.0 & 0.2 & 49.9 \\
\hline $\mathrm{Y}_{2} \mathrm{O}_{3}$ & 31.5 & 0.3 & 0.0 & 0.0 & 0.0 & 0.0 & 18.9 \\
\hline $\mathrm{MgO}$ & 1.8 & 0.0 & 0.0 & 0.3 & 0.0 & 0.2 & 41.8 \\
\hline
\end{tabular}

${ }^{a}$ Reaction conditions: $0.5 \mathrm{~g}$ ball-milled cellulose, $1 \mathrm{~g}$ catalyst $\left(\mathrm{HfO}_{2}\right.$ and $\left.\mathrm{Ga}_{2} \mathrm{O}_{3} 0.5 \mathrm{~g}\right), 50 \mathrm{~g}$ water, $473 \mathrm{~K}$ reaction temperature, $6 \mathrm{~h}$ reaction time.

${ }^{b}$ Others were calculated from the total amount of organic carbon in solution. 


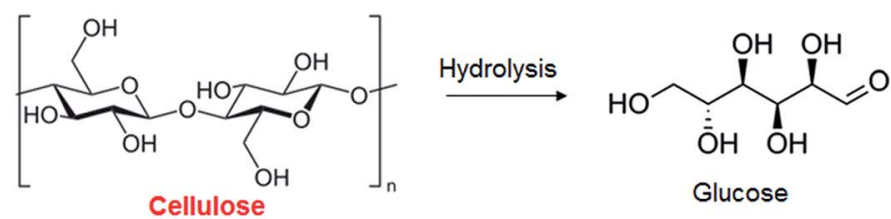<smiles>O=C(CO)C(O)C(O)C(O)CO</smiles><smiles></smiles>

Hydroxymethylfurfural (HMF)<smiles>CC(=O)CCC(=O)O</smiles>

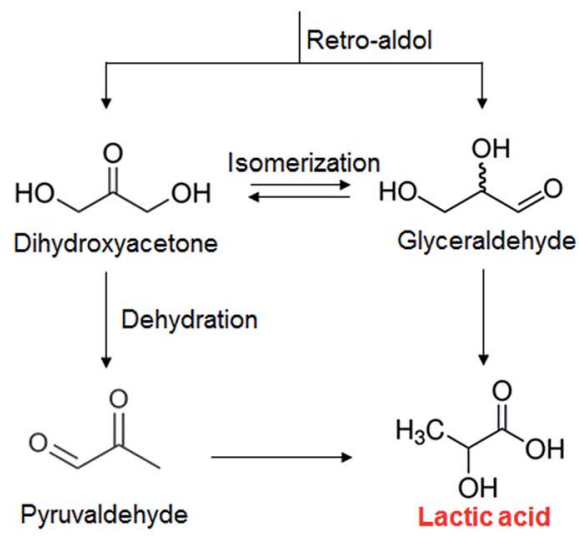

Scheme 1 Proposed mechanism for cellulose conversion into various chemicals.

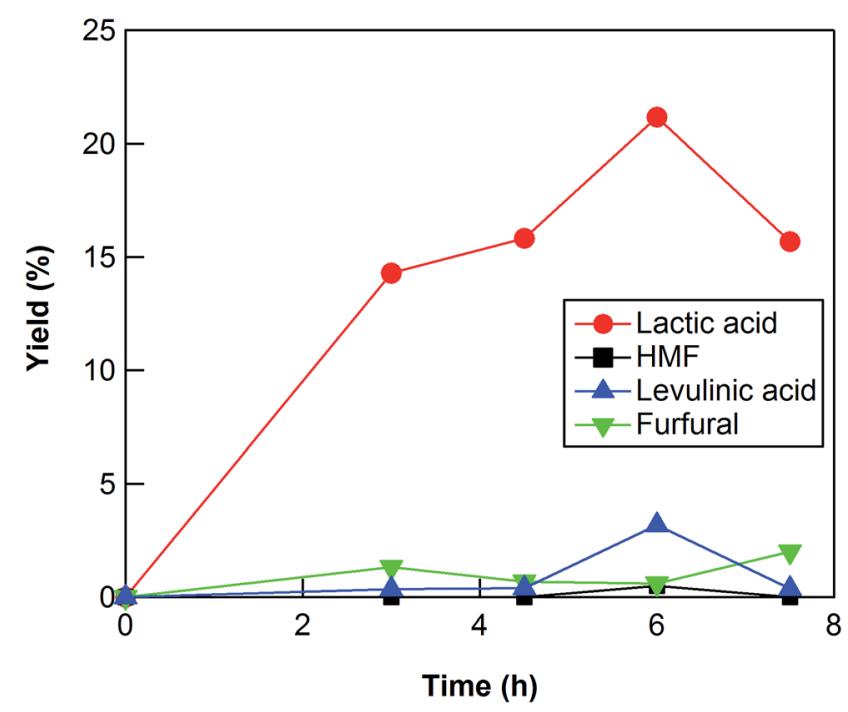

Fig. 1 Cellulose conversion using a $\mathrm{ZrO}_{2}$ catalyst at $473 \mathrm{~K}$ as a function of reaction time. Reaction conditions: $0.5 \mathrm{~g}$ ball-milled cellulose, $1 \mathrm{~g}$ $\mathrm{ZrO}_{2}$ (ZRO-7), $50 \mathrm{~g}$ water.

obtained for a reaction time of $6 \mathrm{~h}$. The maximum yields of lactic acid at 453,463 , and $483 \mathrm{~K}$ were lower than the yield at $473 \mathrm{~K}$, the indication being that a reaction temperature of $473 \mathrm{~K}$ was the optimum temperature for cellulose conversion into lactic acid.

\section{Cellulose conversion over $\mathrm{ZrO}_{2}$ catalysts}

The yields of lactic acid from cellulose at $473 \mathrm{~K}$ using various types of $\mathrm{ZrO}_{2}$ catalysts ranged from $3.1 \%$ to $21.2 \%$ (Table 2). These results indicate that production of lactic acid requires specific active sites on the $\mathrm{ZrO}_{2}$ catalysts and that the concentration of active sites varied widely between $\mathrm{ZrO}_{2}$ catalysts. In the case of a prepared $\mathrm{ZrO}_{2}$ catalyst such as $\mathrm{ZrO}_{2}-773$, the lactic acid yield decreased with increasing calcination temperature from 773 to $1073 \mathrm{~K}$.

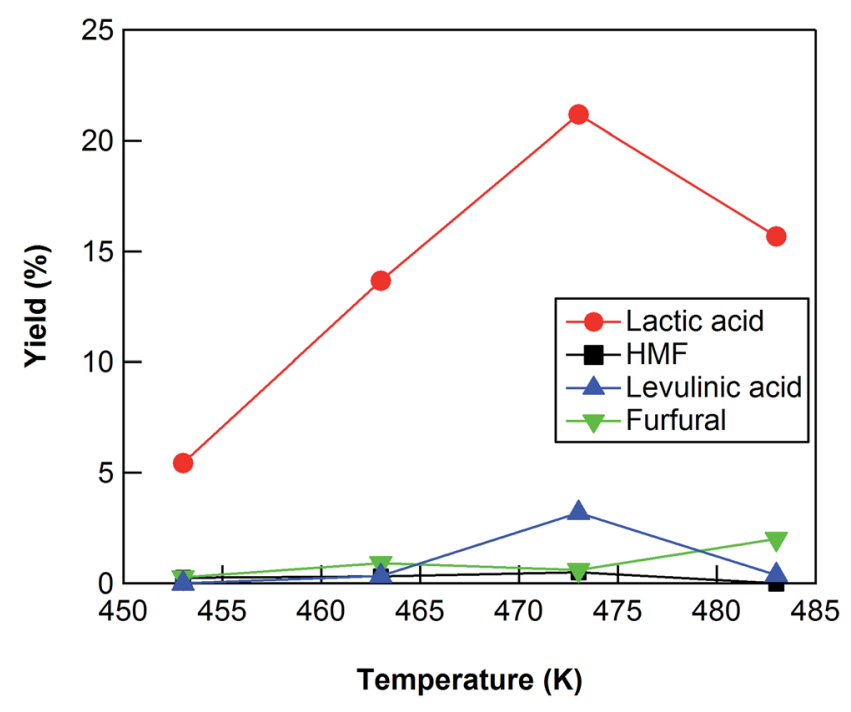

Fig. 2 Cellulose conversion using a $\mathrm{ZrO}_{2}$ catalyst as a function of reaction temperature. Reaction conditions: $0.5 \mathrm{~g}$ ball-milled cellulose, $1 \mathrm{~g} \mathrm{ZrO}_{2}$ (ZRO-7), $50 \mathrm{~g}$ water, $6 \mathrm{~h}$ reaction time.

To elucidate the cause of the differences between the $\mathrm{ZrO}_{2}$ catalytic activities, we characterized the catalysts using XRD, nitrogen adsorption, $\mathrm{NH}_{3}$-TPD, and $\mathrm{CO}_{2}$-TPD (Table 3). The XRD patterns (Fig. $\mathrm{S} 4 \dagger$ ) revealed that the $\mathrm{ZrO}_{2}$ catalysts included monoclinic, monoclinic/tetragonal mixtures, and cubic (only YSZ) crystal structures as well as, and amorphous $\mathrm{ZrO}_{2}$ (Table 3). The crystal sizes of the crystalline $\mathrm{ZrO}_{2}$ ranged from 11.7 to $47.7 \mathrm{~nm}$ (Table 3). Nitrogen adsorption indicated that the specific surface areas ranged widely from 7.7 to $325 \mathrm{~m}^{2} \mathrm{~g}^{-1}$. The crystal phases, crystal sizes, and specific surface areas of the $\mathrm{ZrO}_{2}$ catalysts were poorly correlated with the yields of lactic acid from cellulose at 473 K (Table 3). 
Table 2 Conversion of cellulose into various chemicals using zirconium oxide catalysts ${ }^{a}$

\begin{tabular}{|c|c|c|c|c|c|c|c|}
\hline \multirow[b]{2}{*}{ Catalyst } & \multirow[b]{2}{*}{$\begin{array}{l}\text { Conversion } \\
(\%)\end{array}$} & \multicolumn{6}{|l|}{ Yield (\%) } \\
\hline & & Lactic acid & Glucose & HMF & $\begin{array}{l}\text { Levulinic } \\
\text { acid }\end{array}$ & Furfural & Others $^{b}$ \\
\hline $\mathrm{ZrO}_{2}-\mathrm{Hos}$ & 69.1 & 3.1 & 1.2 & 9.4 & 0.3 & 1.3 & 29.9 \\
\hline $\mathrm{ZrO}_{2}$-Ald & 100.0 & 8.8 & 0.5 & 3.8 & 6.4 & 1.5 & 41.9 \\
\hline $\mathrm{ZrO}_{2}-\mathrm{Nac}$ & 92.8 & 4.9 & 2.0 & 10.6 & 5.4 & 2.8 & 37.7 \\
\hline $\mathrm{ZrO}_{2}$-Wak & 92.0 & 6.9 & 1.0 & 9.0 & 5.0 & 2.0 & 41.3 \\
\hline ZRO-6 & 100.0 & 18.4 & 0.0 & 0.5 & 1.9 & 0.4 & 31.2 \\
\hline ZRO-7 & 87.3 & 21.2 & 0.0 & 0.5 & 3.2 & 0.6 & 39.7 \\
\hline ZRO-8 & 95.4 & 10.9 & 1.4 & 4.1 & 5.1 & 1.6 & 44.4 \\
\hline ZRO-9 & 73.9 & 20.0 & 0.0 & 0.4 & 2.3 & 0.4 & 30.4 \\
\hline YSZ & 89.2 & 6.5 & 1.4 & 11.7 & 4.9 & 1.7 & 38.7 \\
\hline $\mathrm{ZrO}_{2}-773$ & 96.9 & 14.0 & 0.0 & 0.0 & 0.3 & 1.0 & 53.2 \\
\hline $\mathrm{ZrO}_{2}-873$ & 100.0 & 10.4 & 0.0 & 0.9 & 0.3 & 1.2 & 57.3 \\
\hline $\mathrm{ZrO}_{2}-973$ & 100.0 & 8.5 & 0.8 & 3.8 & 2.4 & 1.5 & 51.6 \\
\hline $\mathrm{ZrO}_{2}-1073$ & 98.1 & 6.5 & 0.9 & 3.2 & 1.9 & 1.6 & 56.5 \\
\hline
\end{tabular}

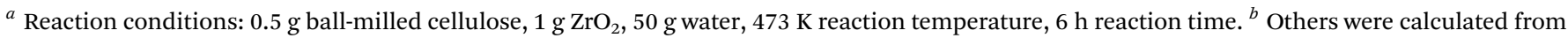
the total amount of organic carbon in solution.

The key step in the production of lactic acid is fructose conversion into glyceraldehyde and dihydroxyacetone by a retro-aldol reaction involving $\mathrm{C}-\mathrm{C}$ bond cleavage (Scheme 1), which is reported to be enhanced by Lewis acid. ${ }^{24-26}$ The acid sites and base sites of metal oxides can be characterized by $\mathrm{NH}_{3}-$ TPD and $\mathrm{CO}_{2}$-TPD, respectively. ${ }^{27-30}$ The desorption temperatures of $\mathrm{NH}_{3}$ from the $\mathrm{ZrO}_{2}$ catalysts were about $470 \mathrm{~K}$ (Fig. S5†), and no $\mathrm{NH}_{3}$ desorption peak was observed at a temperature above $673 \mathrm{~K}$. The indication was that the acid sites on the $\mathrm{ZrO}_{2}$ catalysts were weakly acidic, presumably because they were Lewis acids. ${ }^{28}$ The desorption temperature of $\mathrm{NH}_{3}$ on a Brønsted acid has been reported to be more than $673 \mathrm{~K}^{28}$ The concentration of acid sites was calculated from the $\mathrm{NH}_{3}$ desorption peak area around $470 \mathrm{~K}$ (Table 3). The desorption temperatures of $\mathrm{CO}_{2}$ from the $\mathrm{ZrO}_{2}$ catalysts were $340-450 \mathrm{~K}$ (Fig. S6 $\dagger$ ), indication being that the base sites on the $\mathrm{ZrO}_{2}$ catalysts were weakly basic. ${ }^{30} \mathrm{~A}$ plot of the lactic acid yields as a function of the concentration of acid and base sites on the $\mathrm{ZrO}_{2}$ catalysts (Fig. 3) revealed that the lactic acid yield did not depend on the $\mathrm{ZrO}_{2}$ crystal phase. The results showed almost a linear relationship between the lactic acid yield and the concentration of acid and base sites on the $\mathrm{ZrO}_{2}$ samples. Yang et al. have reported that a combination of Lewis acid and base sites catalyzes xylose conversion into glyceraldehyde and glycolaldehyde via a retro-aldol reaction. ${ }^{24}$ We propose (Scheme 2 ) that the reaction mechanism of fructose conversion into glyceraldehyde and dihydroxyacetone by a retro-aldol reaction involves a combination of acid and base sites on $\mathrm{ZrO}_{2}$. Initially, the carbonyl group of the fructose interacts with the $\mathrm{Zr}$ site of the Lewis acid, and at the same time the $\mathrm{OH}$ group at the position of the C-4 carbon adsorbs onto the $\mathrm{O}$ site of the week base (Scheme 2). Cleavage of the $\mathrm{C}-\mathrm{C}$ bond between the $\mathrm{C}-3$ and $\mathrm{C}-4$ of fructose then leads to the formation of glyceraldehyde and dihydroxyacetone. To understand how $\mathrm{ZrO}_{2}$ catalyzes the conversion of intermediates

Table 3 Structural characterization of zirconium oxides

\begin{tabular}{|c|c|c|c|c|c|c|}
\hline Catalyst & Crystal phase $^{a}$ & $\begin{array}{l}\text { Crystalline } \\
\operatorname{size}^{a}(\mathrm{~nm})\end{array}$ & $\begin{array}{l}\text { Specific surface } \\
\text { area }\left(\mathrm{m}^{2} \mathrm{~g}^{-1}\right)\end{array}$ & $\begin{array}{l}\text { Acid site amount } \\
\left(\mathrm{mmol} \mathrm{g}^{-1}\right)\end{array}$ & $\begin{array}{l}\text { Base site amount } \\
\left(\mathrm{mmol} \mathrm{g}^{-1}\right)\end{array}$ & $\begin{array}{l}\text { Lactic acid } \\
\text { yield }^{b}(\%)\end{array}$ \\
\hline $\mathrm{ZrO}_{2}-\mathrm{Hos}$ & Monoclinic, tetragonal & 44.8 & 19.4 & 0.004 & 0.092 & 3.1 \\
\hline $\mathrm{ZrO}_{2}-\mathrm{Nac}$ & Monoclinic & 47.7 & 7.7 & 0.017 & 0.011 & 4.9 \\
\hline $\mathrm{ZrO}_{2}$-Wak & Monoclinic & 41.9 & 11.7 & 0.024 & 0.028 & 6.9 \\
\hline ZRO-6 & Amorphous & - & $279.3^{c}$ & 0.122 & 0.348 & 18.4 \\
\hline ZRO-9 & Amorphous & - & $325.0^{c}$ & 0.144 & 0.396 & 20.0 \\
\hline YSZ & Cubic & 23.4 & 7.8 & 0.012 & 0.028 & 6.5 \\
\hline $\mathrm{ZrO}_{2}-773$ & Monoclinic, tetragonal & 11.7 & 57.1 & 0.114 & 0.193 & 14.0 \\
\hline $\mathrm{ZrO}_{2}-873$ & Monoclinic & 18.8 & 30.8 & 0.049 & 0.082 & 10.4 \\
\hline $\mathrm{ZrO}_{2}-973$ & Monoclinic & 26.7 & 18.6 & 0.033 & 0.039 & 8.5 \\
\hline $\mathrm{ZrO}_{2}-1073$ & Monoclinic & 25.8 & 17.4 & 0.029 & 0.032 & 6.5 \\
\hline
\end{tabular}

${ }^{a}$ Crystal phase and crystalline size were determined by XRD pattern. ${ }^{b}$ Reaction conditions: $0.5 \mathrm{~g}$ ball-milled cellulose, $1 \mathrm{~g} \mathrm{ZrO}_{2}, 50 \mathrm{~g}$ water, $473 \mathrm{~K}$ reaction temperature, $6 \mathrm{~h}$ reaction time. ${ }^{c}$ Data were shown by the company. 

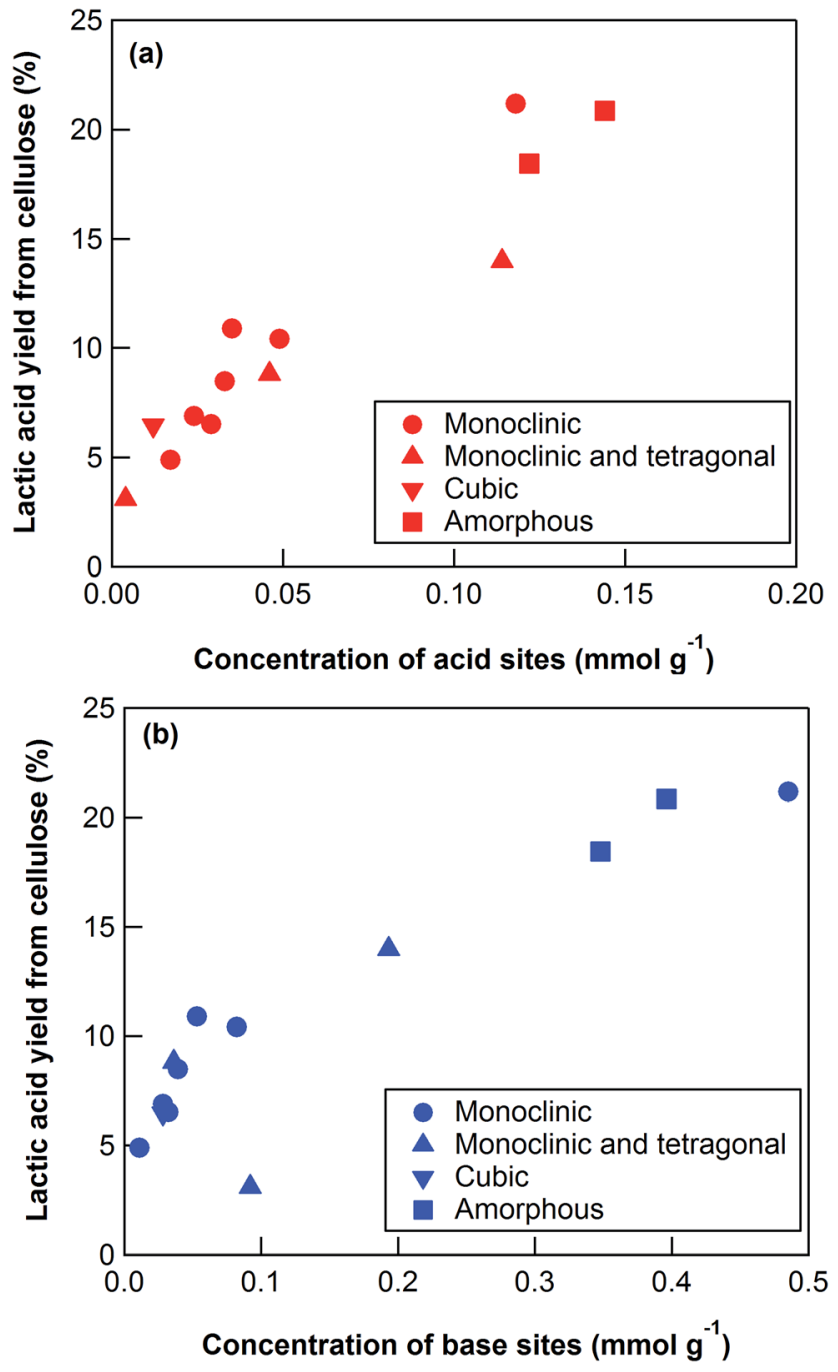

Fig. 3 Lactic acid yield from cellulose using $\mathrm{ZrO}_{2}$ catalysts as a function of the concentration of (a) acid and (b) base sites. Reaction conditions: $0.5 \mathrm{~g}$ ball-milled cellulose, $1 \mathrm{~g} \mathrm{ZrO}_{2}, 50 \mathrm{~g}$ water, $473 \mathrm{~K}$ reaction temperature, $6 \mathrm{~h}$ reaction time.

into lactic acid after the retro-aldol reaction, we used dihydroxyacetone, glyceraldehyde, and pyruvaldehyde as reactants under the same conditions as those used to convert cellulose using $\mathrm{ZrO}_{2}$ (Table 4). Glyceraldehyde, one of the intermediates in the retro-aldol reaction of fructose, was converted into lactic acid whether $\mathrm{ZrO}_{2}$ was present or not, the indication being that the conversion of glyceraldehyde into lactic acid did not require a $\mathrm{ZrO}_{2}$ catalyst, and this step proceeded in high-temperature (473 K) water. Dihydroxyacetone, the other intermediate from the retro-aldol reaction of fructose, was converted into lactic acid, the yield being higher with $\mathrm{ZrO}_{2}(28.7 \%)$ than without $\mathrm{ZrO}_{2}(17.5 \%)$. Without $\mathrm{ZrO}_{2}$, dihydroxyacetone was isomerized into glyceraldehyde, and the glyceraldehyde was then converted into lactic acid. This sequence of reactions occurred because pyruvaldehyde, the other possible intermediate produced from dihydroxyacetone, requires $\mathrm{ZrO}_{2}$ as a catalyst to produce lactic acid. The conversion of pyruvaldehyde into lactic acid was reported to require Lewis acid sites workable in water such as $\mathrm{TiO}_{2} \cdot{ }^{31-33}$ In the case of dihydroxyacetone conversion catalyzed by $\mathrm{ZrO}_{2}$, the $\mathrm{ZrO}_{2}$ catalytically enhanced dihydroxyacetone isomerization into glyceraldehyde or dihydroxyacetone conversion into pyruvaldehyde, and then both glyceraldehyde and pyruvaldehyde were converted into lactic acid with $\mathrm{ZrO}_{2}$ as the catalyst.

\section{Reusability of the $\mathrm{ZrO}_{2}$ catalyst}

ICP analysis indicated that very little $\mathrm{Zr}$ was leached out $\left(10^{-4} \%\right)$ from $\mathrm{ZrO}_{2}$ (ZRO-7) into water during the reaction. We also investigated the extent to which the $\mathrm{ZrO}_{2}$ catalyst could be reused to convert cellulose into lactic acid. After each reaction, the catalyst was separated from the liquid product by filtration, and then it was calcined at $673 \mathrm{~K}$ for $15 \mathrm{~h}$ in air to remove any carbon deposited on the surface of the catalyst. The lactic acid yield decreased slightly after the first reaction (Fig. 4), but it stabilized after the second reaction. After five uses, the ZRO-7 catalyst showed the same XRD patterns as the fresh ZRO-7 catalyst and the concentration of acid sites did not change $\left(0.128 \mathrm{mmol} \mathrm{g}^{-1}\right)$ from $0.118 \mathrm{mmol} \mathrm{g}^{-1}$ of the fresh ZRO-7 catalyst; however, the concentration of base sites decreased to $0.350 \mathrm{mmol} \mathrm{g}^{-1}$ from $0.485 \mathrm{mmol} \mathrm{g}^{-1}$ after five uses, the result being a slight decrease of catalytic activity.

The reported heterogeneous catalysts $\mathrm{LaCoO}_{3},{ }^{12} \mathrm{AlW},{ }^{13}$ and $\mathrm{NbF}_{5}-\mathrm{AlF}_{3}$ (ref. 14) provided 24, 28, and $27 \%$ yield of lactic acid from cellulose, respectively. The catalysts, however, are

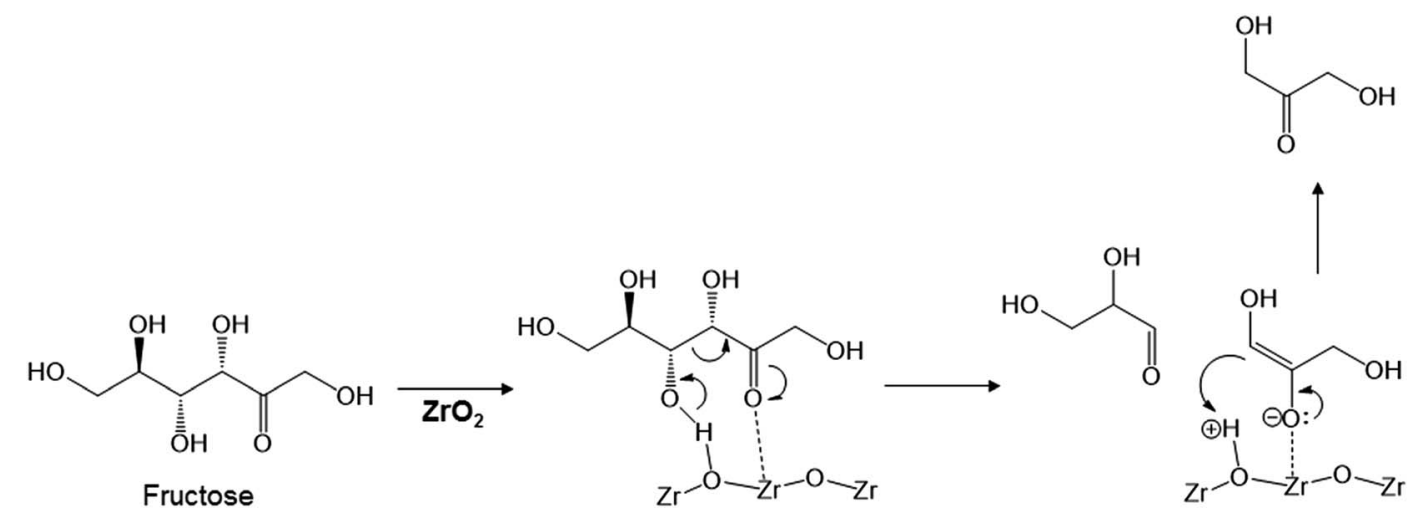

Scheme 2 Proposed mechanism for fructose conversion into glyceraldehyde and dihydroxyacetone by a retro-aldol reaction on acid and base sites of $\mathrm{ZrO}_{2}$. 
Table 4 Conversion of dihydroxyacetone, glyceraldehyde, and pyruvaldehyde with and without zirconium oxide ${ }^{a}$

\begin{tabular}{llllll}
\hline & & \multicolumn{2}{c}{ Yield (\%) } \\
\cline { 3 - 6 } Reactant & Catalyst & $\begin{array}{l}\text { Lactic } \\
\text { acid }\end{array}$ & $\mathrm{HMF}$ & $\begin{array}{l}\text { Levulinic } \\
\text { acid }\end{array}$ & Furfural \\
\hline Dihydroxyacetone & - & 17.5 & 0.0 & 0.0 & 0.0 \\
Dihydroxyacetone & $\mathrm{ZrO}_{2}$ & 28.7 & 0.0 & 0.0 & 0.0 \\
Glyceraldehyde & - & 22.5 & 0.0 & 0.0 & 0.0 \\
Glyceraldehyde & $\mathrm{ZrO}_{2}$ & 24.0 & 0.0 & 0.0 & 0.0 \\
Pyruvaldehyde & - & 1.0 & 0.0 & 0.0 & 0.0 \\
Pyruvaldehyde & $\mathrm{ZrO}_{2}$ & 22.8 & 0.0 & 0.0 & 0.0
\end{tabular}

${ }^{a}$ Reaction conditions: $0.25 \mathrm{~g}$ reactant, $1 \mathrm{~g} \mathrm{ZrO}$ (ZRO-7), $50 \mathrm{~g}$ water, 473 $\mathrm{K}$ reaction temperature, $6 \mathrm{~h}$ reaction time.

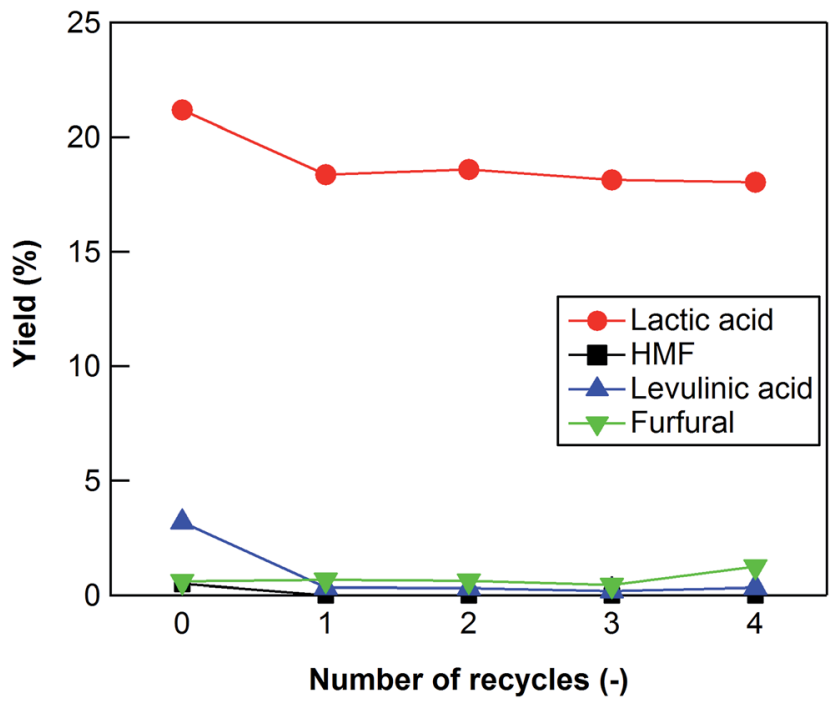

Fig. 4 Cellulose conversion using a recycled $\mathrm{ZrO}_{2}$ catalyst. Reaction conditions: $0.5 \mathrm{~g}$ ball-milled cellulose, $1 \mathrm{~g} \mathrm{ZrO} 2$ (ZRO-7), $50 \mathrm{~g}$ water, $473 \mathrm{~K}$ reaction temperature, $6 \mathrm{~h}$ reaction time.

problematic in that metal species leach from solution during the reaction. Also, the high cost of preparation of these heterogeneous catalysts makes their industrial use problematic. In this study, we showed that relatively inexpensive $\mathrm{ZrO}_{2}$ functions as a catalyst to accelerate the conversion of cellulose into lactic acid (yield $21.2 \%$ ) and that only $10^{-4} \%$ of the $\mathrm{Zr}$ is leached out during the reaction.

\section{Conclusions}

Cellulose conversion into lactic acid was investigated using various transition metal oxides $\mathrm{ZrO}_{2}, \mathrm{Al}_{2} \mathrm{O}_{3}, \mathrm{TiO}_{2}, \mathrm{Fe}_{3} \mathrm{O}_{4}, \mathrm{~V}_{2} \mathrm{O}_{5}$, $\mathrm{CeO}_{2}, \mathrm{Y}_{2} \mathrm{O}_{3}, \mathrm{Tm}_{2} \mathrm{O}_{3}, \mathrm{HfO}_{2}, \mathrm{Ga}_{2} \mathrm{O}_{3}, \mathrm{MgO}, \mathrm{La}_{2} \mathrm{O}_{3}, \mathrm{Nb}_{2} \mathrm{O}_{5}$, and $\mathrm{Ta}_{2} \mathrm{O}_{5}$. The $\mathrm{ZrO}_{2}$ showed catalytic activity for lactic acid production from cellulose (lactic acid yield $21.2 \%$ ) at $473 \mathrm{~K}$ for $6 \mathrm{~h}$. Various types of $\mathrm{ZrO}_{2}$ were also used to convert cellulose to lactic acid. The correlation between lactic acid yields and the characteristic properties of the $\mathrm{ZrO}_{2}$ indicated that the amounts of acid and base sites on the $\mathrm{ZrO}_{2}$ played an important role in cellulose conversion into lactic acid. The combination of acid and base sites on the $\mathrm{ZrO}_{2}$ was hypothesized to enhance the key step of fructose conversion into glyceraldehyde and dihydroxyacetone by a retro-aldol reaction. The $\mathrm{ZrO}_{2}$ catalyst was stable in high-temperature water, and almost no $\mathrm{Zr}$ leached out of the catalyst into solution during the reaction.

\section{Acknowledgements}

We acknowledge Dr Osamu Sato (AIST) for his helpful technical discussions about preparing $\mathrm{ZrO}_{2}$. This study was partially supported by the Thailand Research Fund (IRG5780001) and a NRCT-NSFC joint funding project (NRCT/2558-104).

\section{References}

1 X. Tong, Y. Ma and Y. Li, Appl. Catal., A, 2010, 385, 1-13.

2 H. Kobayashi, T. Komanoya, S. K. Guha, K. Hara and A. Fukuoka, Appl. Catal., A, 2011, 409-410, 13-20.

3 P. Gallezot, Chem. Soc. Rev., 2012, 41, 1538-1558.

4 R. Datta and M. Henry, J. Chem. Technol. Biotechnol., 2006, 81, 1119-1129.

5 P. Mäki-Arvela, I. L. Simakova, T. Salmi and D. Y. Murzin, Chem. Rev., 2014, 114, 1909-1971.

6 D. Garlotta, J. Polym. Environ., 2001, 9, 63-84.

7 K. M. Nampoothiri, N. R. Nair and R. P. John, Bioresour. Technol., 2010, 101, 8493-8501.

8 S. Varadarajan and D. J. Miller, Biotechnol. Prog., 1999, 15, 845-854.

9 F. A. C. Martinez, E. M. Balciunas, J. M. Salgado, J. M. D. González, A. Converti and R. P. D. S. Oliveira, Trends Food Sci. Technol., 2013, 30, 70-83.

10 Y. Wang, W. Deng, B. Wang, Q. Zhang, X. Wan, Z. Tang, Y. Wang, C. Zhu, Z. Cao, G. Wang and H. Wan, Nat. Commun., 2013, 4, 2141.

11 X. Lei, F.-F. Wang, C.-L. Liu, R.-Z. Yang and W.-S. Dong, Appl. Catal., A, 2014, 482, 78-83.

12 X. Yang, L. Yang, W. Fan and H. Lin, Catal. Today, 2016, 269, 56-64.

13 F. Chambon, F. Rataboul, C. Pinel, A. Cabiac, E. Guillon and N. Essayem, Appl. Catal., B, 2011, 105, 171-181.

14 S. M. Coman, M. Verziu, A. Tirsoaga, B. Jurca, C. Teodorescu, V. Kuncser, V. I. Parvulescu, G. Scholz and E. Kemnitz, ACS Catal., 2015, 5, 3013-3026.

15 J. Yu and P. E. Savage, Appl. Catal., B, 2001, 31, 123-132.

16 M. Watanabe, H. Inomata and K. Arai, Biomass Bioenergy, 2002, 22, 405-410.

17 J. A. Wang, M. A. Valenzuela, J. Salmones, A. Vázquez, A. García-Ruiz and X. Bokhimi, Catal. Today, 2001, 68, 21-30.

18 A. Yamaguchi, N. Hiyoshi, O. Sato, K. K. Bando and M. Shirai, ChemSusChem, 2010, 3, 737-741.

19 A. Yamaguchi, O. Sato, N. Mimura, Y. Hirosaki, H. Kobayashi, A. Fukuoka and M. Shirai, Catal. Commun., 2014, 54, 22-26.

20 J. M. R. Gallo, D. M. Alonso, M. A. Mellmer and J. A. Dumesic, Green Chem., 2013, 15, 85-90. 
21 R. Weingarten, W. C. Conner Jr and G. W. Huber, Energy Environ. Sci., 2012, 5, 7559-7574.

22 F. Jin, Z. Zhou, H. Enomoto, T. Moriya and H. Higashijima, Chem. Lett., 2004, 33, 126-127.

23 B. M. Kabyemela, T. Adschiri, R. M. Malaluan and K. Arai, Ind. Eng. Chem. Res., 1999, 38, 2888-2895.

24 L. Yang, J. Su, S. Carl, J. G. Lynam, X. Yang and H. Lin, Appl. Catal., B, 2015, 162, 149-157.

25 L. Yang, X. Yang, E. Tian and H. Lin, ChemSusChem, 2016, 9, 36-41.

26 L. Yang, X. Yang, E. Tian, V. Vattipalli, W. Fan and H. Lin, J. Catal., 2016, 333, 207-216.

27 K. Tomishige, Y. Ikeda, T. Sakaihori and K. Fujimoto, J. Catal., 2000, 192, 355-362.
28 M. E. Manríquez, T. López, R. Gómez and J. Navarrete, J. Mol. Catal. A: Chem., 2004, 220, 229-237.

29 M. Watanabe, Y. Aizawa, T. Iida, R. Nishimura and H. Inomata, Appl. Catal., A, 2005, 295, 150-156.

30 Z.-Y. Ma, C. Yang, W. Wei, W.-H. Li and Y.-H. Sun, J. Mol. Catal. A: Chem., 2005, 227, 119-124.

31 K. Nakajima, R. Noma, M. Kitano and M. Hara,J. Phys. Chem. C, 2013, 117, 16028-16033.

32 M. Hara, Bull. Chem. Soc. Jpn., 2014, 87, 931-941.

33 P. P. Pescarmona, K. P. F. Janssen, C. Delaet, C. Stroobants, K. Houthoofd, A. Philippaerts, C. De Jonghe, J. S. Paul, P. A. Jacobs and B. F. Sels, Green Chem., 2010, 12, 1083-1089. 